This item was submitted to Loughborough's Research Repository by the author.

Items in Figshare are protected by copyright, with all rights reserved, unless otherwise indicated.

\title{
A morphometric comparison of the Namib and southwest Kalahari dunefields using ASTER GDEM data
}

PLEASE CITE THE PUBLISHED VERSION

PUBLISHER

(C) Elsevier

VERSION

AM (Accepted Manuscript)

\section{PUBLISHER STATEMENT}

This work is made available according to the conditions of the Creative Commons Attribution-NonCommercialNoDerivatives 4.0 International (CC BY-NC-ND 4.0) licence. Full details of this licence are available at: https://creativecommons.org/licenses/by-nc-nd/4.0/

\section{LICENCE}

CC BY-NC-ND 4.0

\section{REPOSITORY RECORD}

White, Kevin, Joanna E. Bullard, lan Livingstone, and Lisa Moran. 2019. "A Morphometric Comparison of the Namib and Southwest Kalahari Dunefields Using ASTER GDEM Data”. figshare.

https://hdl.handle.net/2134/19097. 


\title{
A morphometric comparison of the Namib and southwest Kalahari dunefields using ASTER GDEM data
}

Kevin White (corresponding author) ${ }^{1}$, Joanna Bullard ${ }^{2}$, lan Livingstone ${ }^{3}$, Lisa Moran ${ }^{1}$,

1. University of Reading, Department of Geography and Environmental Science, Whiteknights, Reading, RG6 6AB, UK. Email k.h.white@reading.ac.uk, tel +118 3787752

2. Loughborough University, Department of Geography, Martin Hall Building, Loughborough, Leicestershire, LE11 3TU, UK. Email j.e.bullard@Iboro.ac.uk

3. University of Northampton, Avenue Campus, St George's Avenue, Northampton, NN2 6JD, UK. Email ian.livingstone@northampton.ac.uk

\begin{abstract}
The increased availability of digital elevation models and satellite image data enable testing of morphometric relationships between sand dune variables (dune height, spacing and equivalent sand thickness), which were originally established using limited field survey data. These long-established geomorphological hypotheses can now be tested against very much larger samples than were possible when available data were limited to what could be collected by field surveys alone. This project uses ASTER Global Digital Elevation Model (GDEM) data to compare morphometric relationships between sand dune variables in the southwest Kalahari dunefield to those of the Namib Sand Sea, to test whether the relationships found in an active sand sea (Namib) also hold for the fixed dune system of the nearby southwest Kalahari. The data show significant morphometric differences between the simple linear dunes of the Namib sand sea and the southwest Kalahari; the latter do not show the expected positive relationship between dune height and spacing. The southwest Kalahari dunes show a similar range of dune spacings, but they are less tall, on average, than the Namib sand sea dunes. There is a clear spatial pattern to these morphometric data; the tallest and most closely spaced dunes are towards the southeast of the Kalahari dunefield; and this is where the highest values of equivalent sand thickness result. We consider the possible reasons for the observed differences and highlight the need for more studies comparing sand seas and dunefields from different environmental settings.
\end{abstract}

\section{Highlights}

- Morphometric data on linear dunes of the southwest Kalahari are derived from a DEM

- With these data we map dune height, dune spacing and equivalent sand thickness

- We compare these data to similar dunes in the Namib sand sea

- We identify different morphometric relationships from those previously reported

- We discuss implications of these differences for understanding aeolian environments

\section{Key words}

Linear dunes, Aeolian processes, Namib sand sea, Kalahari, Morphometric analysis 


\section{Introduction}

Morphometric analysis is a long established technique in aeolian geomorphology (Wilson, 1972 Bullard et al., 1995; Fitzsimmons, 2007) and has provided numerous insights into dune forming processes and controls (Mabbutt and Wooding, 1983; Thomas, 1988; Wasson et al., 1988). The aim of much of this research is to derive empirical relationships between measurements of dune form (typically dune height and dune spacing), and to see how these relationships respond to changes in controlling variables, such as wind variability and sediment supply. A major limitation for much of this early work was the need for detailed field survey to obtain the necessary measurements; the amount of data yielded from field campaigns often being insufficient for robust statistical modelling. Nevertheless, relationships among variables were suggested, and in many cases these relationships were subsequently used to estimate unmeasured parameters. For example, relationships between dune spacing and dune height derived from field data were used to estimate dune heights from dune spacings derived from aerial photography and other sources (Wasson and Hyde, 1983a). Despite such efforts, the small sample sizes used necessitated care in interpreting the resulting data in terms of dune forming processes.

The availability of Digital Elevation Models (DEMs) from remote sensing missions such as Shuttle Radar Topography Mission (SRTM) (Rabus et al., 2003) and Advanced Spaceborne Thermal Emission and Reflection Radiometer (ASTER) (Slater, 2011) have the potential to provide a robust sampling of dune morphometric data (Hugenholtz et al., 2012). SRTM data have been used to map aspects of dune morphometry in small areas of dunefields such as the Namib, Taklimakan and Australian dunefields (Blumberg, 2006; Bubenzer and Bolten, 2008; Potts et al., 2008), however, data quality is hampered by poor radar returns from sand surfaces, resulting in missing data over sand seas (Bubenzer and Bolten, 2008). In contrast, ASTER uses photogrammetry to estimate spot heights from parallax between the nadir and backward-looking NIR images, and permits much better retrievals of heights over sand than interferometric methods (Slater, 2011) and a global DEM (ASTER GDEM), produced from these data, was released in June 2009 , with a $30 \mathrm{~m}$ horizontal resolution and an estimated absolute vertical uncertainty of c. $6 \mathrm{~m}$ (Telfer et al., 2015). ASTER DEMs provide considerable opportunities for two- and three-dimensional studies of aeolian sand dunes, although there are some limitations, particularly associated with spatial resolution and vertical accuracy in some areas (Hugenholtz and Barchyn, 2010). However, ASTER GDEM data are becoming the most widely used source of DEM data for studies of dunefields and sand seas (Telfer et al., 2015) and these data were selected for use in this study.

Bullard et al. (2011) demonstrated that dune morphometric relationships derived from ASTER GDEM data of the Namib sand sea, on the Atlantic coast of southern Africa (Figure 1), are broadly comparable with relationships derived by previous methods and across a range of different dune types. The Namib sand sea comprises a complex range of active aeolian bedforms, including various types of linear dune, star dunes, barchan fields and transverse ridges (Livingstone et al., 2010). The ASTER GDEM data confirmed patterns of dune height, spacing and equivalent sand thickness mapped previously in the Namib Sand Sea, but the ability to extend the analysis across the entire dunefield $\left(34000 \mathrm{~km}^{2}\right)$ also added new detail to these patterns. 


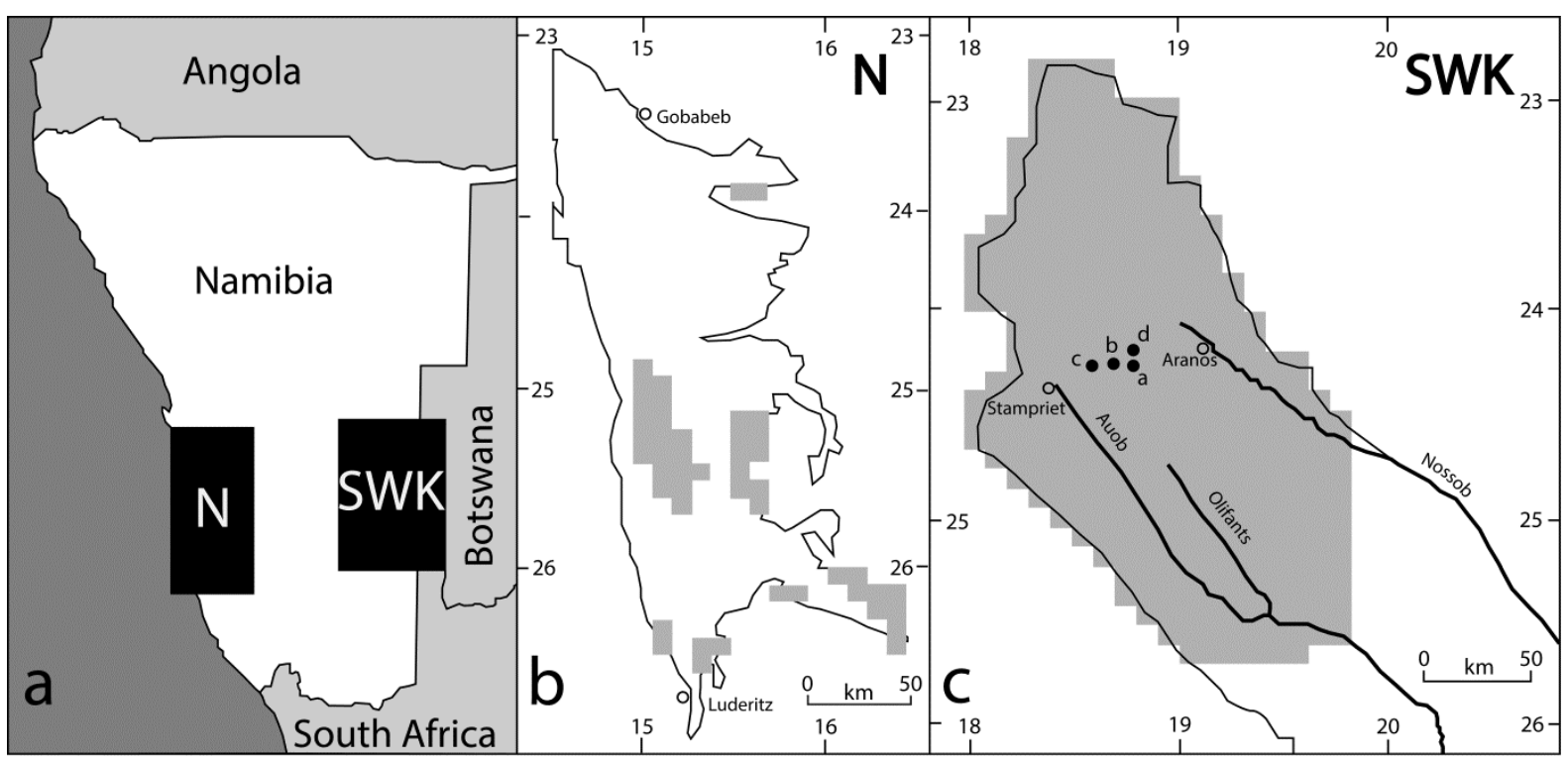

Figure 1: Location map, showing places mentioned in the text. (a) Location of Namib sand sea (N) and southwest Kalahari dunefield (SWK). (b) Sampled $10 \mathrm{~km}$ grid squares in the Namib sand sea (simple linear dunes) shown in grey, solid line shows outline of the sand sea. (c) Sampled $10 \mathrm{~km}$ grid squares in the southwest Kalahari shown in grey, solid line shows outline of the dunefield. Filled dots show location of 2012 field survey transects a-d, shown in Figure 2.

We seek to apply the morphometric analyses of Bullard et al. (2011) to the southwest Kalahari dunefield which has very different dune characteristics compared to the Namib sand sea. Extending about 100,000 $\mathrm{km}^{2}$ (McKee, 1979), the southwest Kalahari covers a substantially larger area than the Namib but contains a much narrower range of dune types. Lancaster (1987) describes the southwest Kalahari dunes as predominantly simple linear dunes, covering between a third and a half of the total sand sea area. These are mostly located in the northern part of the sand sea; towards the south more complex bifurcating or compound linear forms are more common (Thomas, 1988) and localised patches of parabolic dunes also occur (Breed and Grow, 1979; Eriksson et al., 1989). For the same dune type, the southwest Kalahari dunes typically have lower heights and narrower spacings compared with those in the Namib, although there is some overlap in the range of morphometries; for example simple linear dunes in the southwest Kalahari are typically 6 to $20 \mathrm{~m}$ in height, with wavelengths varying from 110 to $1050 \mathrm{~m}$ (Thomas, 1988; Bullard et al., 1995) whereas simple linear dunes in the Namib have heights averaging $22 \mathrm{~m}$ (range 7-66 $\mathrm{m}$ ) and wavelengths averaging $972 \mathrm{~m}$ (475-2674 m) (Bullard et al., 2011). The lower height of the dunes in the southwest Kalahari is likely to have an impact on our ability to measure them using ASTER GDEM data.

Bubenzer and Bolten (2008) suggested that ASTER DEM data could only detect dunes taller than 20$30 \mathrm{~m}$ in the Namib and Hugenholtz and Barchyn (2010) were unable to detect dunes less than $15 \mathrm{~m}$ tall in the Badain Jaran, China.

In addition to being at the suggested limit or threshold for detection of dune heights, the southwest Kalahari dunes are also less active than the Namib sand dunes because the majority have a partial vegetation cover. The Namib sand sea is a coastal desert with a hyperarid climate and consequently there is very little vegetation on the dunes and they have bare, active surfaces (Livingstone, 2013). Aridity decreases with increasing distance inland such that, although the western margin of the southwest Kalahari dunefield is only $200 \mathrm{~km}$ away from the eastern margin of the Namib sand sea in places (Figure 1), climate conditions are very different. The southwest Kalahari dunes experience an arid climate receiving primary summer rainfall of less than $200 \mathrm{~mm}$ annual rainfall but which is 
sufficient to sustain a vegetation cover on the linear dunes (Goudie, 2002). The impact of vegetation on linear dune morphology has been widely discussed (Ash and Wasson, 1983; Wiggs et al., 1996). Furthermore, the presence of vegetation on dunes may make it more difficult to determine dune height from the ASTER GDEM if there is no clearly-defined crest and also due to its potential for affecting the apparent level of the surface of the dune from photogrammetry. The impact of vegetation on DEM accuracy may be spatially varied in the southwest Kalahari because there is not a uniform cover of vegetation on the dunes; typically the plinths are more densely vegetated than the dune crests. The vegetation of the southwest Kalahari is classified as Kalahari xeric savannah, known locally as thornvelt, comprising grasses interspersed with trees dominated by Acacias (Camel Thorn Vachellia erioloba, Grey Camel Thorn Vachellia haematoxylon and Blackthorn Senegalia mellifera) (van Rooyena and van Rooyena, 1998). Grove (1969) notes these grow to $3 \mathrm{~m}$ high on the dune flanks and up to $5 \mathrm{~m}$ high, scattered at intervals of $10-20 \mathrm{~m}$ in the interdunes. Vegetation cover also varies temporally in the dunefield in response to cyclic patterns of precipitation (Bullard et al., 1997; Thomas and Leason, 2005) and this can result in changing dune activity (and potentially dune crest morphology) through time, which could affect the data from which the ASTER GDEM was derived.

The linear dunes of the southwest Kalahari are part of an extensive system of vegetated dunes that are thought to have been in existence prior to $32 \mathrm{ka}$., and reactivated on a number of occasions (Lancaster, 1989). Recent dating work using Optically Stimulated Luminescence (OSL) have demonstrated marked variations in dates of accumulation periods between different dune records (Stone and Thomas, 2008; Thomas and Burrough, 2013). Stone and Thomas (2008) reported the oldest dates for dune accumulation in the study area, indicating that dunes were already present $>186 \pm 16 \mathrm{ka}$. Miller (2014) noted that the original emplacement of the dunes predates the incision of the rivers that cut through the southwest Kalahari dunefield, the Auob, Nossob and Olifants (Figure 1c). He suggests that the original emplacement of the southwest Kalahari dunes was initiated during an arid climatic phase at about 3.2 Ma, with further development during the subsequent arid phases, and with significant remobilization and reworking during the Upper Pleistocene and Holocene (Miller, 2014). Telfer and Thomas (2007) identified phases of accumulation at 15-9, 21-19, 35-27, 57-52, 77-76 and 105-95 ka, for the linear dunes at Witpan, immediately south of the study area. Despite these differences, we can conclude that the southwest Kalahari dunes have probably been present throughout the past six marine isotope stages, and have been partially active not only throughout much of the Holocene, but also through much of the late Quaternary (Stone and Thomas, 2008).

The aim of this paper is to examine the morphometric relationships for the southwest Kalahari linear dunes, derived from ASTER GDEM data, and compare them with data from similar dunes in the Namib sand sea. This analysis includes only simple linear dunes, as defined by McKee (1979), which occur in both dunefields and comprise $7 \%\left(2290 \mathrm{~km}^{2}\right)$ of the Namib dunefield and $30 \%\left(30,494 \mathrm{~km}^{2}\right)$ of the southwest Kalahari dunefield, defined here as morphometric classes 1, 2 and 3 of Bullard et al. (1995). Morphometric class 1 dunes are parallel/subparallel, discontinuous, occurring as short lengths $(<2 \mathrm{~km}), Y$-junctions are uncommon and there are no transverse elements. Morphometric class 2 dunes are parallel/subparallel and continuous for several $\mathrm{km}$, few $\mathrm{Y}$-junctions, no (or very rare) transverse elements and occasional small slip faces on crests. Morphometric class 3 dunes are parallel/subparallel, continuous for several $\mathrm{km}, \mathrm{Y}$-junctions are common with short spurs $<600 \mathrm{~m}$ on either side of the dunes, with no slip faces, except where grazing has occurred. First we determine whether the relationship between field survey and ASTER GDEM data is consistent between the simple linear dunes of the Namib and southwest Kalahari dunefields. Second, we use ASTER GDEM data to map the spatial distribution of morphometric variables within the simple linear dunes of the southwest Kalahari, and test whether relationships determined for the active simple linear dunes of the Namib sand sea can also be identified for the vegetated simple linear dunes of the southwest Kalahari. 


\section{Data analysis}

\subsection{Comparison of ASTER DEM data with field survey data}

Prior to carrying out any data analysis with the ASTER GDEM data, we first compare survey transects taken from the DEM with those taken in the field to assess how representative the GDEM data are of the actual dune topography. Four field surveys, covering six individual dune profiles, collected by Differential GPS survey during August 2012 in the southwest Kalahari (see Figure 1 for location of transects) were compared to ASTER GDEM data for the same transect lines (Figure 2); five similar profile comparisons were conducted by Bullard et al. (2011) for the Namib sand sea. Dune heights and cross sectional areas were extracted from both field and GDEM transects (Figure 3 ). The dunes in the SW Kalahari are significantly smaller than those in the Namib; the heights of field surveyed dunes in the Namib ranged from 50 to $102 \mathrm{~m}$, while those surveyed in the SW Kalahari ranged from 11 to $20 \mathrm{~m}$. However, they lie on a continuum such that the relationship between GDEM and fieldderived data can be argued to be consistent for both dunefields, with the derived regression functions (Figure 3 ) underestimating dune height and cross sectional area by about $10 \%$ on average, compared to field survey data. Although the southwest Kalahari GDEM surveys appear much less smooth than those of the Namib (probably due to the effect of trees and shrubs on the southwest Kalahari dunes which can reach $5 \mathrm{~m}$ height - Figure 4), the relationships between field surveyed heights and cross sectional areas are consistent with those derived from the GDEM data (Figure 3). These data suggest that it is possible to extract dune morphometric data from ASTER GDEM for the smaller vegetated dunes of the southwest Kalahari using a similar methodology to that used in the Namib. However, we first use the relationships established in Figure 3 to correct the GDEM derived dune heights and cross sectional areas to estimated field surveyed dune heights and cross sectional areas, prior to all further data analysis. This was done in order to ensure our data were as comparable as possible with that used by Wasson and Hyde (1983a) and other previous studies based on field survey data. 
a

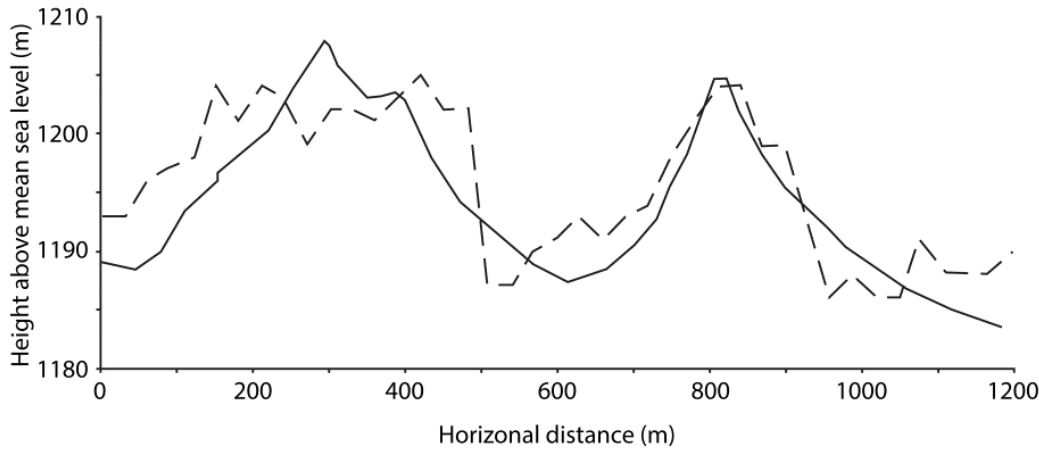

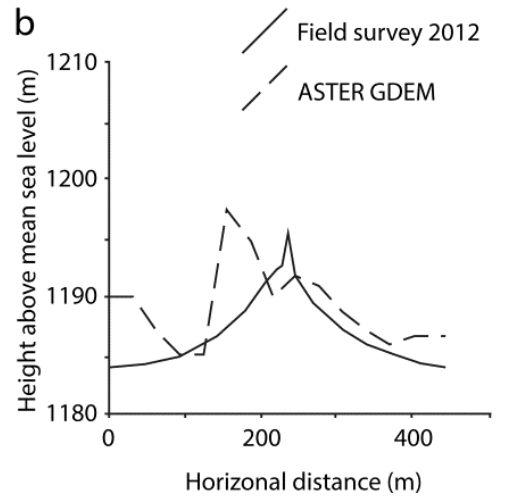

d

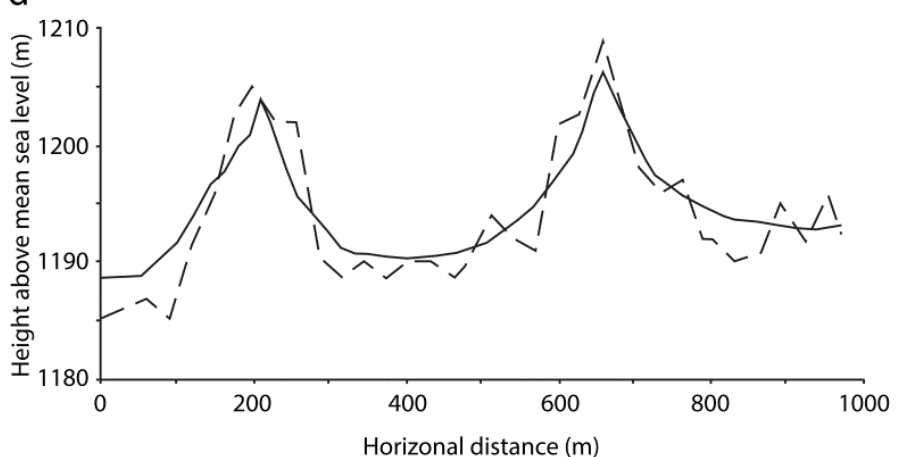

Figure 2: Comparison of topographic transects derived from ASTER DEM and field DGPS survey in the southwest Kalahari dunefield. Locations of transects a-d shown in Figure 1c. 
a

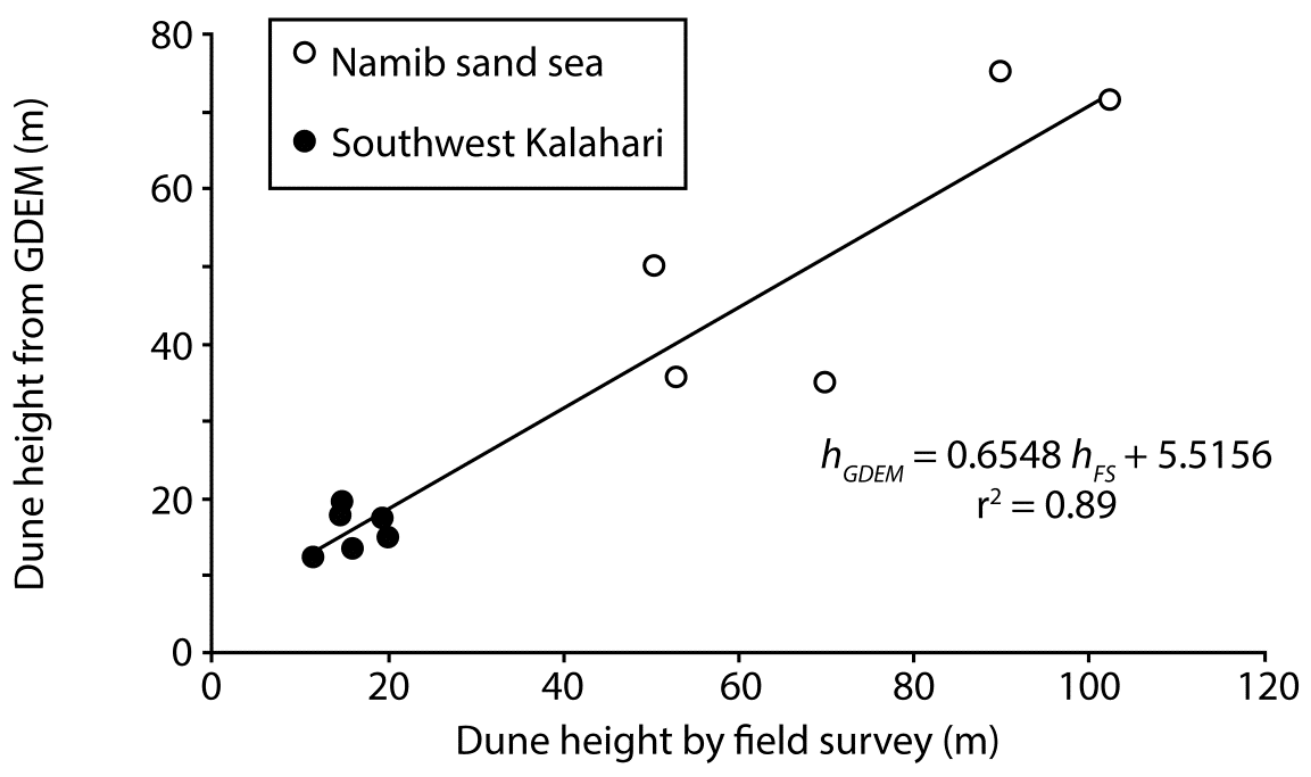

b

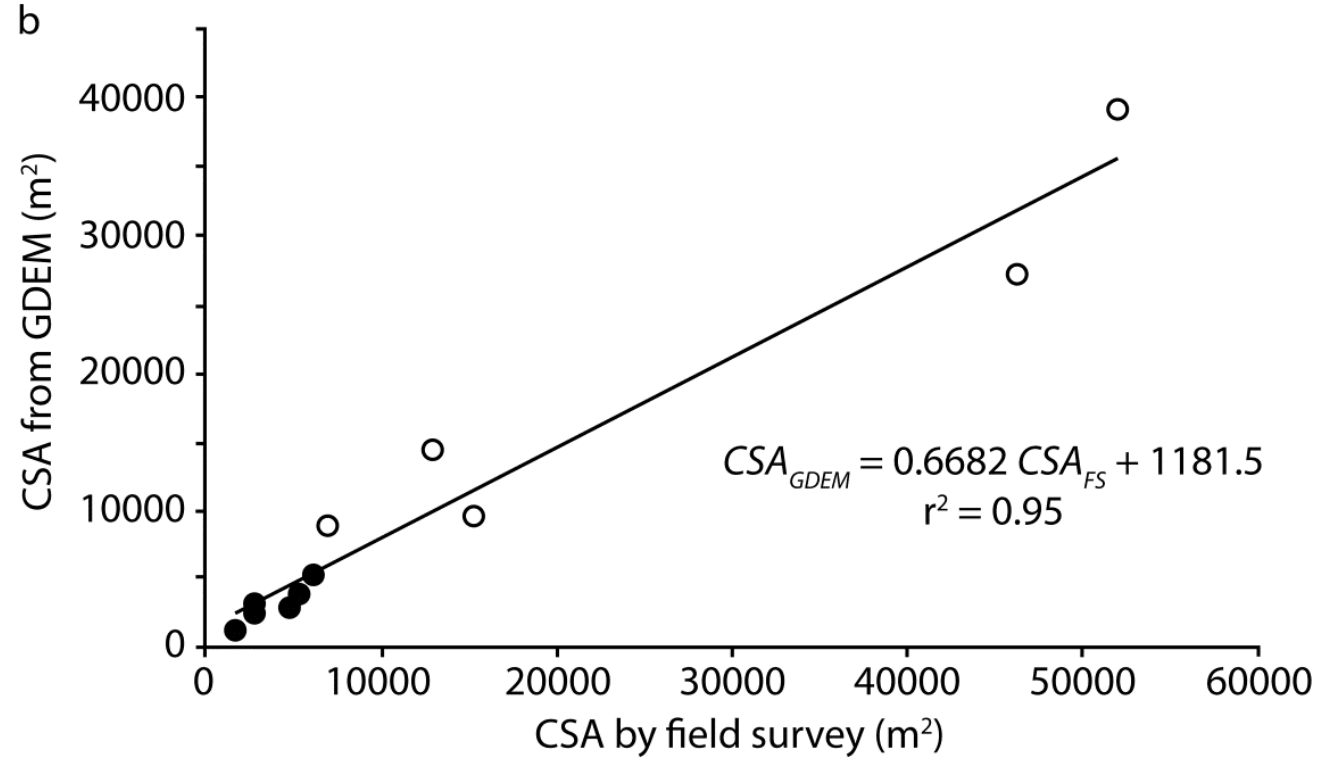

Figure 3: (a) Comparison of dune heights derived from field survey $\left(h_{F S}\right)$ and GDEM profiles $\left(h_{\text {GDEM }}\right)$ (b) comparison of cross sectional areas derived from field survey $\left(C S A_{F S}\right)$ and GDEM profiles $\left(C S A_{G D E M}\right)$. 


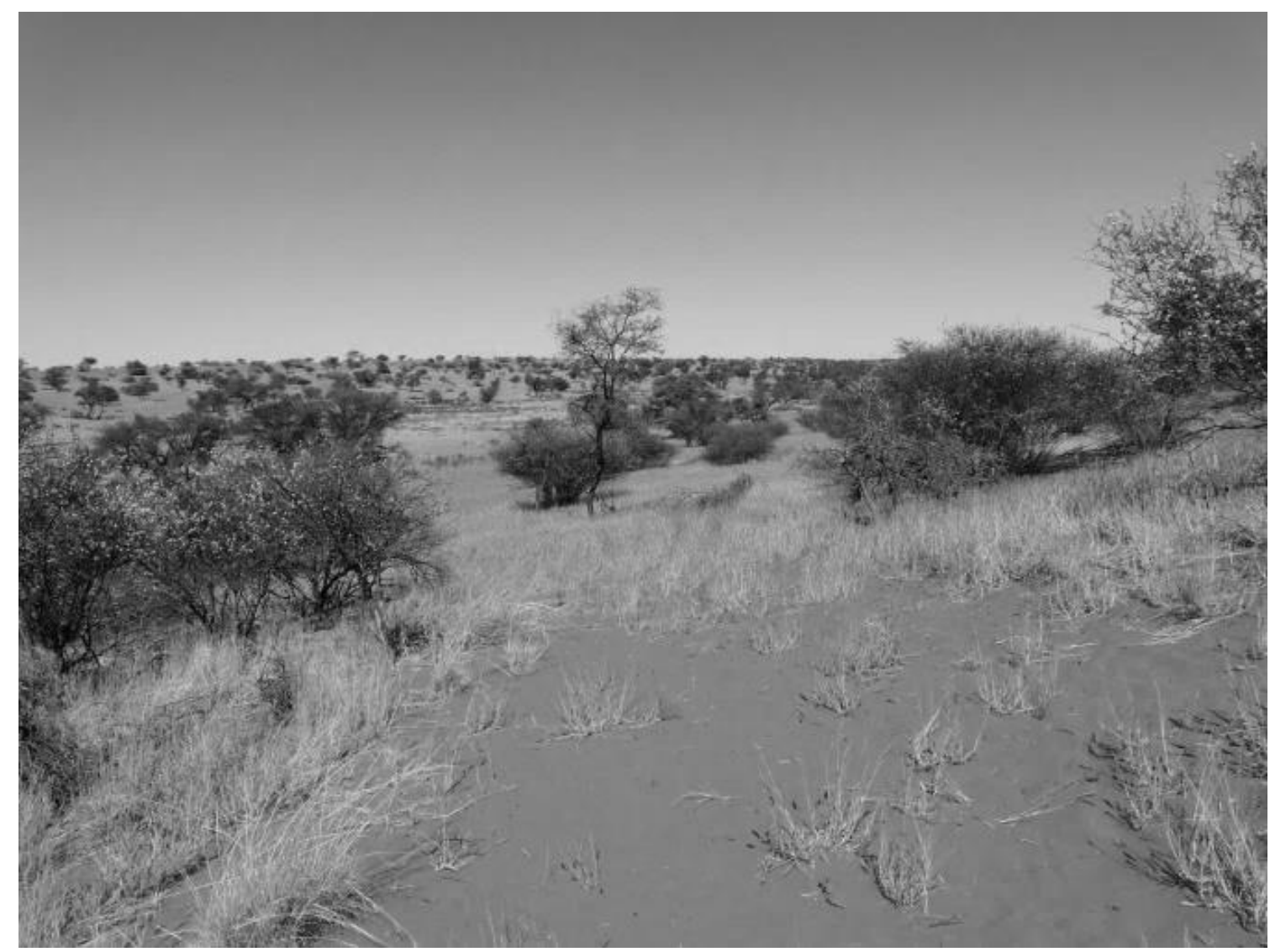

Figure 4: Photograph of the linear dunes of the southwest Kalahari, showing vegetation cover

\subsection{Extracting gridded morphometric data from ASTER DEM data}

In order to extract morphometric data from the southwest Kalahari dunes we adopted the same methodology as Bullard et al. (2011). Using GIS software, a polygon is drawn around the dunefield to contain only the region of simple linear dunes for analysis (the solid line in Figure 1c). For the southwest Kalahari this comprised the area of the dunefield between 18.15 to $19.75^{\circ} \mathrm{E}$ and 23.05 to $25.45^{\circ} \mathrm{S}$, characterised as dune classes 1,2 or 3 by Bullard et al. (1995). Then a $10 \mathrm{~km}$ by $10 \mathrm{~km}$ grid is overlain on the GDEM data (the grey squares shown in Figure $1 \mathrm{c}$ ) and a $10 \mathrm{~km}$ transect is drawn perpendicular to the linear dune orientation, passing though the centre of each grid square. A $10 \mathrm{~km}$ grid was used so our data would be comparable with Bullard et al. (2011). GDEM elevations (30 m postings) are then extracted along the transect for further analysis. For each $10 \mathrm{~km}$ transect, the locations of dune crests and edges are noted manually and checked against optical (Landsat Enhanced Thematic Mapper) imagery within the GIS software. This systematic sampling scheme was then used to generate descriptive statistics of the dune transects on a regular grid. No attempt was made to clean the data or remove artefacts; no such problems were identified during the analysis. 246 dune transects were analysed in this way.

Once the transect elevation values have been imported into a spreadsheet, morphometric data can be derived. Although the calculations can be automated, a high level of user input is required to ensure edges and crests of dunes are correctly positioned with reference to the Landsat Thematic Mapper imagery, thereby avoiding errors resulting from non-dune topographic features such as small channels and hills in the interdune areas. For each dune, dune height $(\mathrm{h})$ is determined using:

$$
h=E_{\text {max }}-\left(\frac{E_{1}+E_{n}}{2}\right)
$$


(Eq. 1)

Figure 5 shows the derivation of $h$ from 30 m elevation postings $\left(E_{1}-E_{n}\right)$ from the ASTER GDEM. Dune spacing is measured as the crest-to-crest distance measured in DEM cells. Each cell is $30 \mathrm{~m}$ by $30 \mathrm{~m}$, but unless the transect is drawn exactly along NS or EW direction, the real spacing is a function of number of pixels multiplied by $30 \mathrm{~m}$, then multiplied by a coefficient that varies between 1 (for NS or EW transects) and 1.4142 for transects at 045 degrees or 135 degrees azimuth. This simple correction allows for comparison of dune spacings derived from different azimuthal transects. Dune cross sectional area (CSA) is determined using:

$$
C S A=\left(\frac{\Sigma E_{1-n}}{n}\right)-\left(\frac{E_{1}+E_{n}}{2}\right)
$$

Having measured each individual dune along the transect, the following morphometric properties can be derived to describe each $10 \mathrm{~km}$ grid square, which we refer to as a block.

a) Mean and standard deviation of dune height for each $10 \mathrm{~km}$ block

b) Mean and standard deviation of dune spacing for each $10 \mathrm{~km}$ block

c) Total dune cross sectional area (Total CSA) along each $10 \mathrm{~km}$ transect

d) Equivalent sand thickness (Total CSA/transect length)

SI units (metres) are used throughout the analysis.

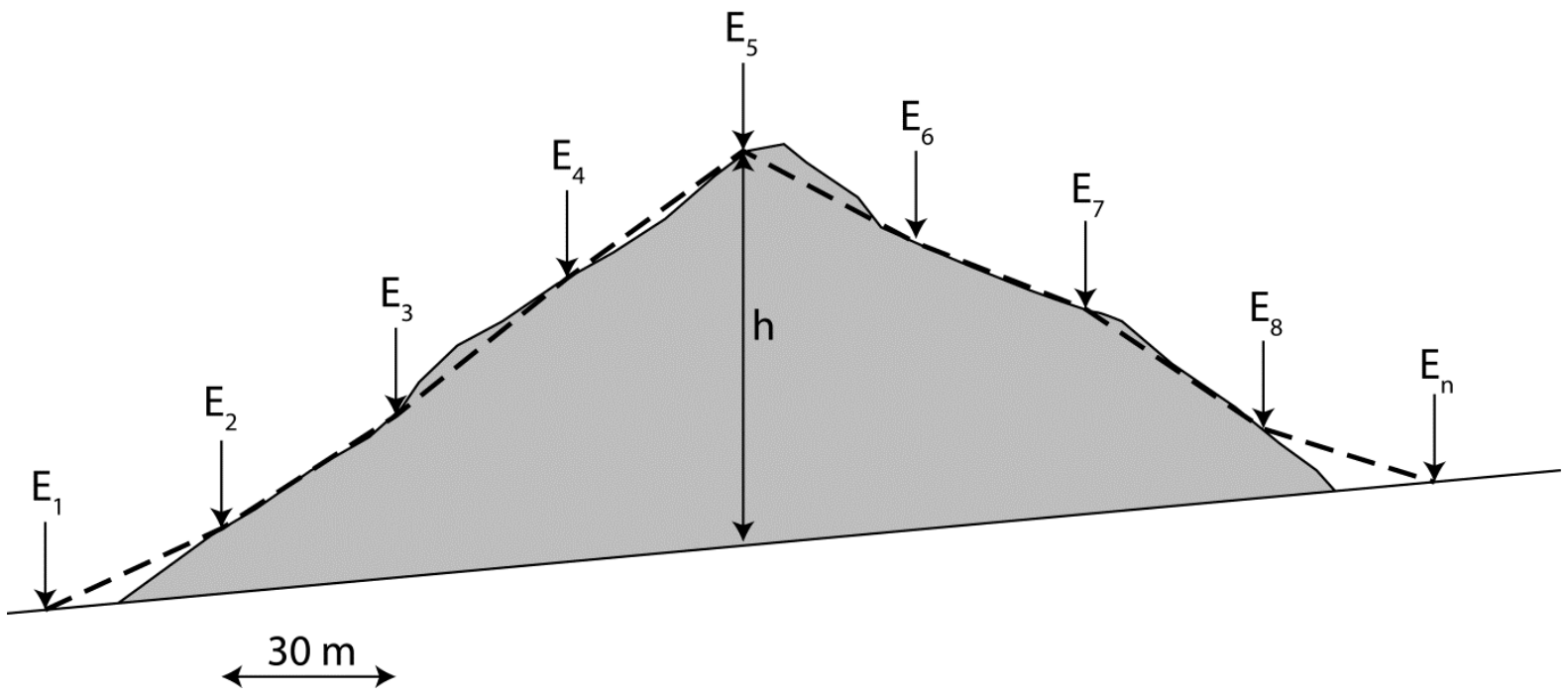

Figure 5: Derivation of dune height ( $h$ ) from $30 \mathrm{~m}$ ASTER GDEM elevation postings $\left(E_{1}-E_{n}\right)$. Grey area is actual dune cross section, dashed line is dune transect represented by ASTER GDEM. $E_{\max }=E_{5}$ in this example.

\subsection{Mapping spatial variations in dune morphometry}

Using GIS software, maps are produced showing the spatial variations in these parameters for each $10 \mathrm{~km}$ block (Figure 6). The morphometric relationships between these parameters for the 
southwest Kalahari are then compared with the results of the same analyses for the sixty $10 \mathrm{~km}$ cells characterised by simple linear dunes only of the Namib sand sea (Figure 7 and 8).

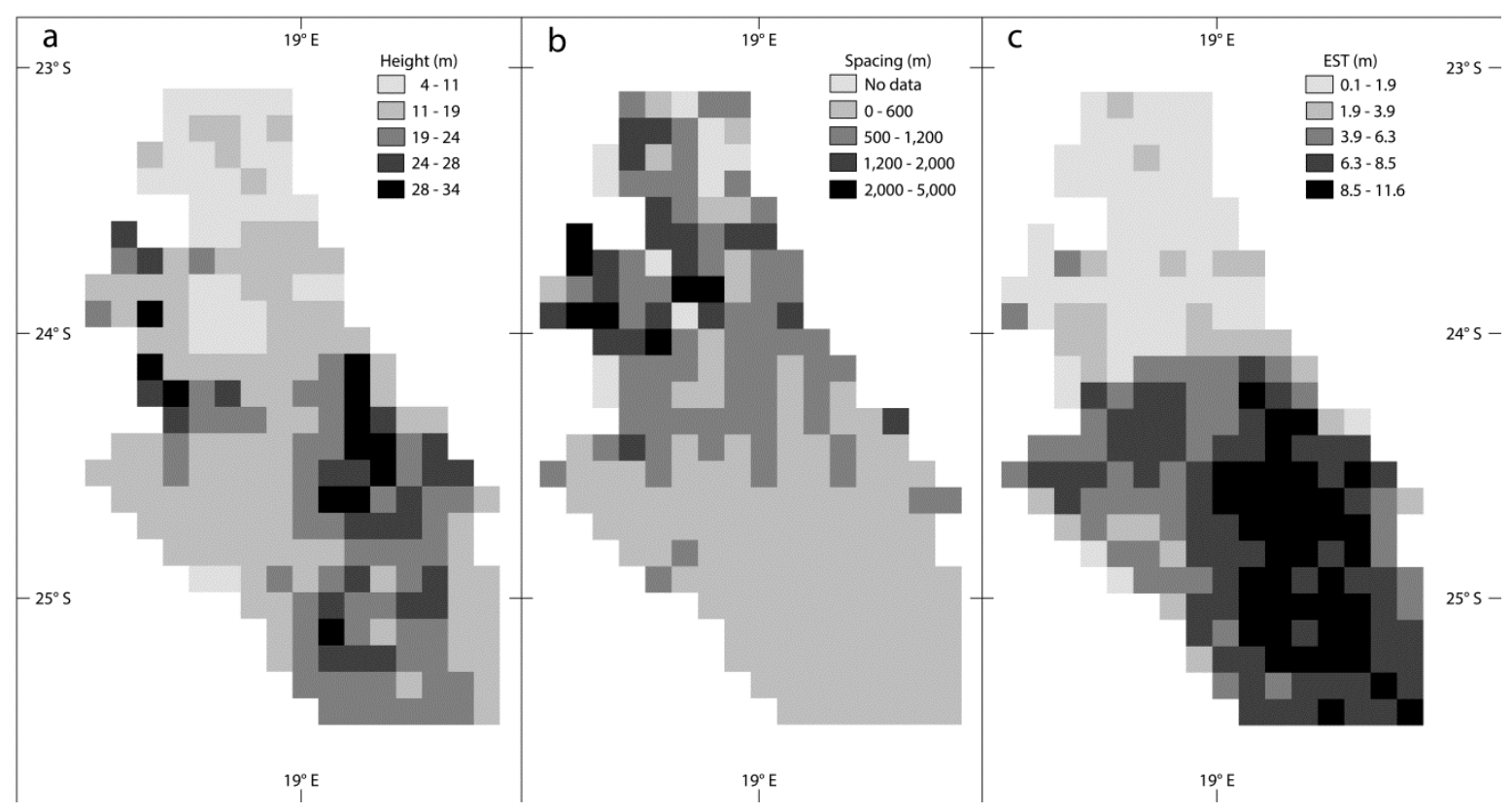

Figure 6: Maps of (a) dune height (b) dune spacing and (c) equivalent sand thickness for the southwest Kalahari dunefield. The 'No data' category in dune spacing map (b) refers to cells with only one dune crest present, thereby precluding measurement of dune spacing. 


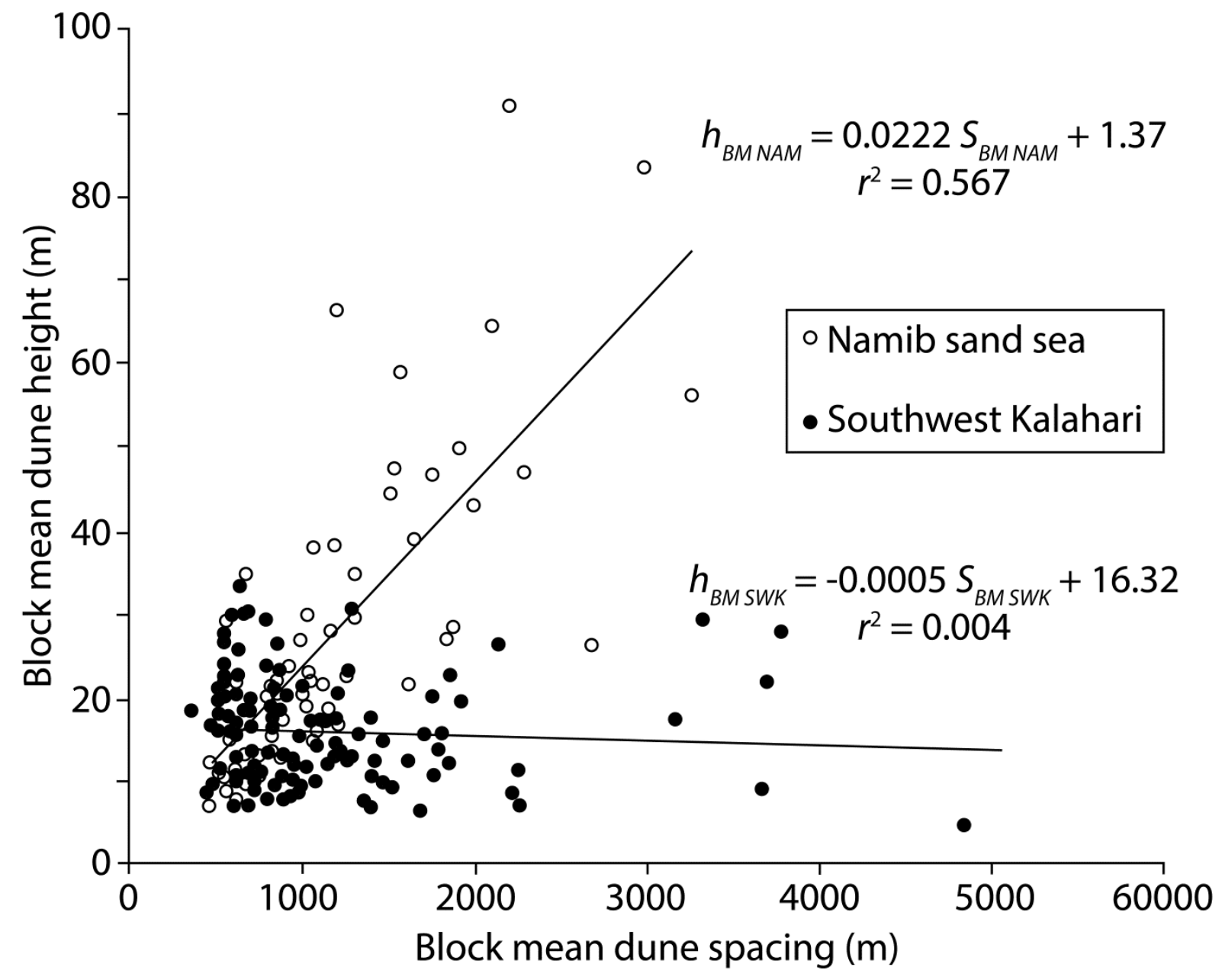

Figure 7: The relationships between transect-averaged (block mean) dune height and dune spacing for the southwest Kalahari and Namib sand seas. $h_{B M}$ NAM are the block mean dune heights of the Namib sand sea, $S_{B M N A M}$ are the block mean dune spacings of the Namib sand sea, $h_{B M}$ swK are the block mean dune heights of the southwest Kalahari, and $S_{B M}$ swK are the block mean dune spacings of the southwest Kalahari. 


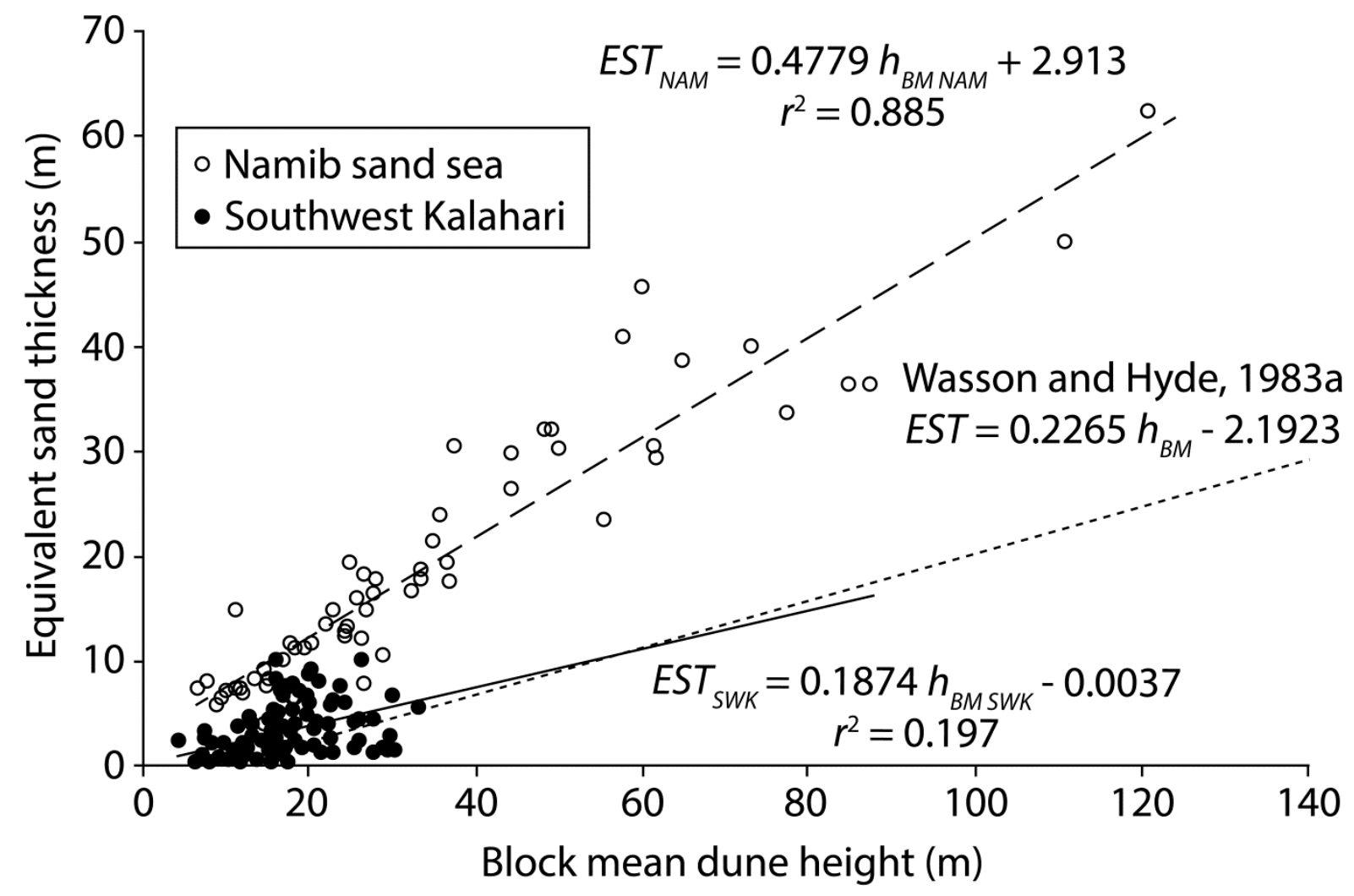

Figure 8: The relationships between dune height and equivalent sand thickness for the southwest Kalahari (solid line) and the Namib sand sea (dashed line). EST $T_{N A M}$ are the equivalent sand thicknesses of the Namib sand sea, $E S T_{S W k}$ are the equivalent sand thicknesses of the southwest Kalahari. The relationship found by Wasson and Hyde (1983a) is also shown (dotted line).

\section{Discussion}

Figure 6 shows that the tallest dunes, and also those containing the greatest equivalent sand thickness, lie to the southeast of the mapped area of the southwest Kalahari. Within the mapped area, dune height increases from northwest to southeast; block mean dune height varies from 5.3 to $26.4 \mathrm{~m}$ (standard deviation $4.52 \mathrm{~m}$, coefficient of variation 0.30 ). In contrast, dune spacing decreases from northwest to southeast, block mean dune spacing varies from 3724 to $4868 \mathrm{~m}$ (standard deviation $621 \mathrm{~m}$, coefficient of variation 0.76 ). Comparison of coefficients of variation show that block mean dune heights are relatively less variable than block mean dune spacings. Several researchers have identified positive relationships between dune height and dune spacing, for example in the Namib sand sea (Bullard et al., 2011, Besler, 1980, Lancaster, 1988a, 2009), the Simpson-Strzelecki and Great Sandy deserts of Australia (Wasson and Hyde, 1983b) and also previous studies of the southwest Kalahari dunefield (Lancaster, 1988a; Thomas, 1988). In contrast, our data for this part of the southwest Kalahari show no significant relationship $\left(r^{2}=0.004\right)$ between dune height and dune spacing (Figure 7).

The relationships between dune height and spacing from other studies vary from dunefield to dunefield and also within dunefields (Table 1). The relationship between dune height and spacing proposed by Thomas (1988) and Lancaster (1988a) for the southwest Kalahari dunefield are not the same; Thomas (1988) suggests dune height increase more rapidly with spacing than Lancaster (1988a). Bullard (1994) examined the relationship between block mean dune height and spacing for the southwest Kalahari dunefield (between $18^{\circ} 14^{\prime}$ and $22^{\circ} 0^{\prime} \mathrm{E}$, and $23^{\circ} 45^{\prime}$ and $28^{\circ} 0^{\prime} \mathrm{S}$ ) using a 
range of methods including field surveys and aerial photograph analysis and, in contrast to previous studies, she was unable to establish a statistically significant relationship between the two variables across the entire dunefield. However, Bullard (1994) noted that the relationship varied spatially within the dunefield and within sub-types of simple linear dunes. When considering only one subtype of dunes (morphometric class 3, parallel to sub-parallel dunes with frequent y-junctions), Bullard et al. (1995) found the relationship between dune height and spacing was significant $199 \%$ level; $n=98$ ). There was also a spatial variability in the relationship for all dunes; Bullard (1994) did find height/spacing relationships in the southern half of the dunefield (outside the area considered in this paper), albeit less significant than that reported by Thomas (1988) or Lancaster (1988a). However, Bullard (1994) was unable to find any statistically significant relationships for the northern part of the dunefield studied here.

\begin{tabular}{|c|c|c|c|}
\hline Reference & $\begin{array}{l}h \text { (dune height) and } S \text { (dune } \\
\text { spacing) relationship }\end{array}$ & ror $r^{2}$ & Dunefield \\
\hline $\begin{array}{l}\text { Lancaster, } \\
1988 \text { a }\end{array}$ & $\ln h=-4.254+1.103 \ln S$ & $r=0.72$ & $\begin{array}{l}\text { Linear dunes, Southwest } \\
\text { Kalahari }\end{array}$ \\
\hline Thomas, 1988 & $h=0.06 S+2.92$ & $r^{2}=0.56$ & $\begin{array}{l}\text { Linear dunes, Southwest } \\
\text { Kalahari }\end{array}$ \\
\hline $\begin{array}{l}\text { Wasson \& Hyde } \\
\text { 1983a }\end{array}$ & $h=0.0182 S-0.4196$ & $r^{2}=0.852$ & $\begin{array}{l}\text { Linear dunes, Simpson- } \\
\text { Strzelecki, Australia }\end{array}$ \\
\hline $\begin{array}{l}\text { Wasson \& } \\
\text { Hyde, 1983a }\end{array}$ & $h=0.0041 S+4.4053$ & $r^{2}=0.457$ & $\begin{array}{l}\text { Linear dunes, Great Sandy } \\
\text { Desert, Australia }\end{array}$ \\
\hline Wilson, 1973 & $h=0.1668 S-179.56$ & Not given & $\begin{array}{l}\text { Linear dunes 'draas', } \\
\text { Algeria }\end{array}$ \\
\hline Lancaster, 1995 & $h=0.0705 S-51.069$ & $r^{2}=0.51087$ & $\begin{array}{l}\text { Complex linear dunes, } \\
\text { Namib }\end{array}$ \\
\hline Lancaster, 1995 & $h=0.0134 S+11.15$ & $r^{2}=0.488$ & $\begin{array}{l}\text { Complex linear dunes, } \\
\text { Namib }\end{array}$ \\
\hline $\begin{array}{l}\text { Lancaster, } \\
1988 b\end{array}$ & $\begin{array}{l}\text { Generic formulation of } \\
h=c S^{n} \text { where c is a } \\
\text { constant and } \mathrm{n} \text { is an } \\
\text { exponent. } \\
h=\mathrm{c} S^{0.54} \\
\begin{array}{l}h=\mathrm{c} S^{1.72} \\
h=c S^{1.06}\end{array} \\
h=c S^{0.52} \\
h=c S^{1.10}\end{array}$ & $\begin{array}{l}r=0.66 \\
r=0.72 \\
r=0.67 \\
r=0.70 \\
r=0.81\end{array}$ & $\begin{array}{l}\text { Compound linear, Namib } \\
\text { Complex linear, Namib } \\
\text { Linear, Simpson-Strezlecki, } \\
\text { Australia } \\
\text { Linear, Great Sandy, } \\
\text { Australia } \\
\text { Linear, southwestern } \\
\text { Kalahari }\end{array}$ \\
\hline
\end{tabular}

Table 1: Relationships between linear dune height and spacing reported from previous studies 
Thomas (1988) only sampled dunes south of $25^{\circ} 30^{\prime} \mathrm{S}$ and with spacings less than $230 \mathrm{~m}$. In addition, a substantial number of the dunes measured in the field by Thomas (1988) were located adjacent to river valleys. Linear dunes in the southwest Kalahari can have significantly different morphological characteristics (including spacing) within $10 \mathrm{~km}$ either side of river valleys compared with those further away from the valley (Bullard and Nash, 1998) due to the influence of valleys on overlying airflow structures (Bullard et al., 2000; Wiggs et al., 2002), and this could have affected the morphometric data collected. Lancaster (1988a) sampled 21 dunes throughout the dunefield with a wider range of dune spacing (175 to $800 \mathrm{~m}$ ).

The most appropriate data with which to compare the ASTER GDEM data generated in this paper are Bullard's (1994) field and airphoto surveys of 42 dunes north of $25^{\circ} \mathrm{S}$ (corresponding to the area mapped for this paper). Comparing the southwest Kalahari data with Bullard's (1994) data (Figure 9), indicates that, although the overall patterns are similar, the dune transects sampled for the Bullard (1994) study were, on average, less tall and less widely spaced than the transects sampled here. However, in both cases the strength of the relationship is very weak. The range of dune heights and spacings determined by both methods is similar. These data support our finding that the relationship between dune height and spacing in the area of the southwest Kalahari mapped here does not follow the expected positive relationship, with bigger dunes being spaced further apart. Comparing the Kalahari data from the GDEM analyses with that from the simple linear dunes of the Namib sand sea (Figure 7), the Namib dunes are taller than southwest Kalahari dunes on average, but their spacings are comparable. One possible interpretation of this, discussed further below, is that, post dune emplacement, the southwest Kalahari dunes have lost height, potentially as a result of their fixed nature and decrease in sand supply.

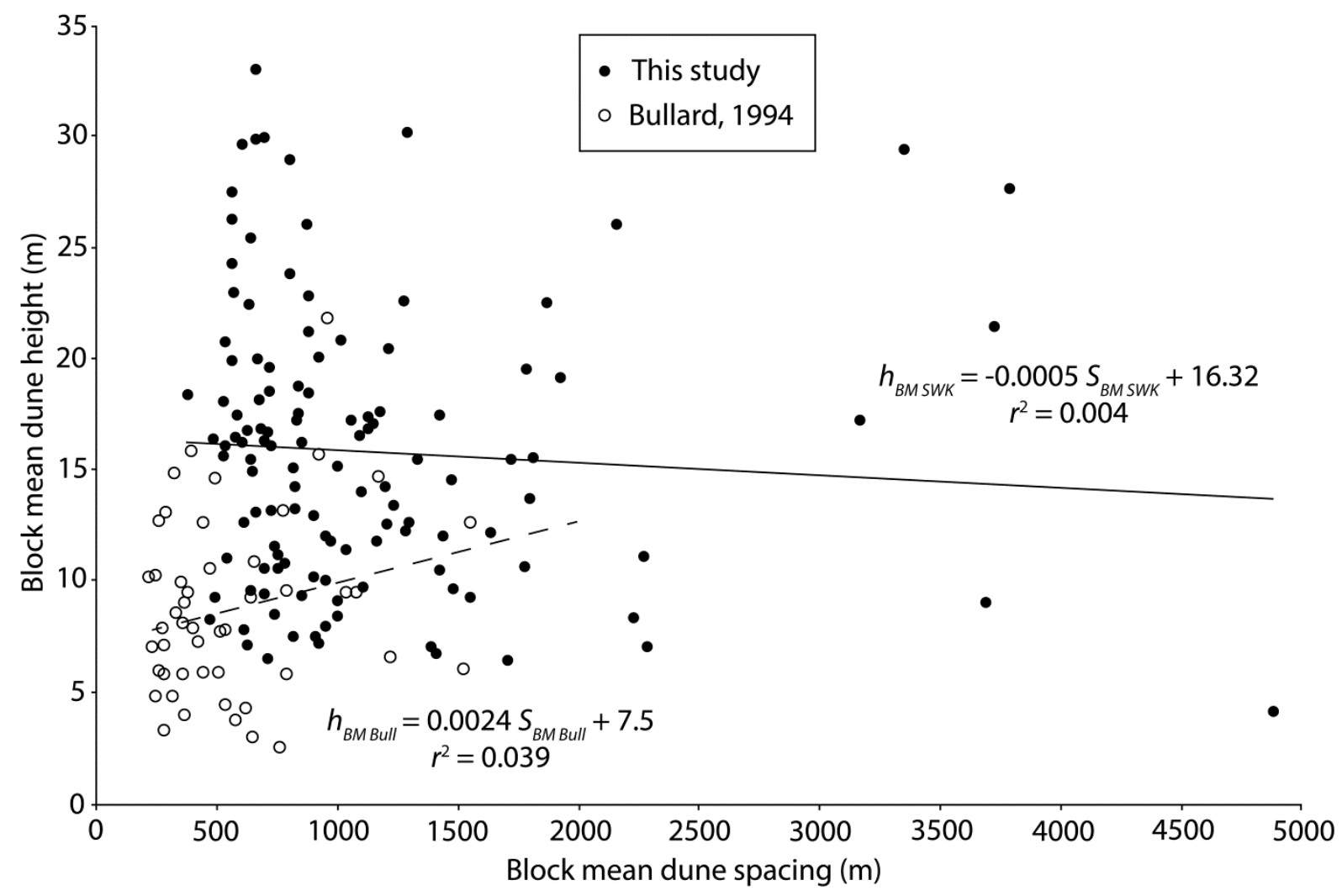

Figure 9: The relationship between dune height and dune spacing found by Bullard (1994) (dashed line) in the southwest Kalahari, compared with the southwest Kalahari data produced in this study 
(solid line), reproduced from Figure 7. $h_{B M B \text { Bull }}$ are the block mean dune heights from Bullard (1994) and $S_{B M}$ Bull are the block mean dune spacings from Bullard (1994).

The relationship between EST and dune height is also quite different when comparing the Namib sand sea and southwest Kalahari (Figure 8). The comparison is limited by the fact that the Namib simple linear dunes extend over a much larger range of dune heights. Furthermore, the EST values encountered in the southwest Kalahari correspond only to the lowest part of the range found in the Namib simple linear dunes. The relationship found in the southwest Kalahari appears similar to that found by Wasson and Hyde (1983a). The least squares functions fitted to these relationships predict lower values of EST for any given mean dune height in the southwest Kalahari compared to the Namib. The low overall values of EST in the southwest Kalahari support the assertion of Grove (1969) that the sand ridges could have been formed from an original flat sheet of sand with a thickness of little more than one or two metres. Within the study area, the majority of the sand volume is contained within the taller, most closely spaced dunes towards the southeast (Figure 6c).

There are three possible interpretations of these differences in morphometric relationships between the simple linear dunes of the southwest Kalahari and the Namib sand seas. Firstly, the methodology adopted for this study may have introduced artifacts into the DEM measurement process, perhaps due to limitations with extracting dune height data from the smaller vegetated dunes of the Kalahari. We discount this interpretation on the basis that comparison of field and DEM derived metrics for the southwest Kalahari show very similar differences to those for the (unvegetated) Namib sand sea (Bullard et al., 2011). Secondly, the southwest Kalahari dunes may have been formed under significantly different conditions of wind regime and sediment supply, resulting in the observed morphometric differences at the time of dune formation. Thirdly, the southwest Kalahari dunefield may have been subjected to post depositional modifications during the Holocene, which has resulted in significant changes to the morphometric relationships considered here. These relationships depend on sediment availability (Kocurek et al., 1992), the impact of upwind dune height on flow regime (Frank and Kocurek, 1996; Baddock et al., 2007) and interdune characteristics (Twidale, 1972) and may break down if dunes are no longer actively maintained by suitable sand transporting winds and sediment supply (Mainguet and Chemin, 1983; Kocurek et al., 1992; Kiss et al., 2009). Some workers have suggested that low wind velocities limit sand movement in the southwest Kalahari, but Bullard et al. (1997) demonstrate significant interannual variability during the period 1960-1992, with considerable potential for sand transport. Wiggs et al. (1995) showed that the limiting variables on surface sediment movement vary on different parts of these dunes. On interdunes and lower dune slopes the primary limiting variable is available wind energy, while on dune crests and upper slopes it is vegetation cover.

Post depositional modifications of the southwest Kalahari dune profiles could have come about in two different ways (Kiss et al., 2009); firstly as a result of increased aeolian activity due to land-use changes, overgrazing or climate fluctuations (Muhs and Holliday, 1995) which mostly promote deflation in the form of blowouts (Vance and Wolfe, 1996); secondly as a result of increased runoff, which might remove sand volume from the dunes by gullying (Sweeney and Loope, 2001; Talbot and Williams, 1978). In a study of fixed parabolic dunes in Hungary, Kiss et al. (2009) noted that the eroded dune material is not transported far; it accumulates at the foot of the dune, rearranging its slope profile, but not altering the area of its cross section. They estimated that the eroded dunes were 4.0-6.5 $\mathrm{m}$ lower than their original height.

However, the OSL studies of Telfer and Thomas (2007) and Stone and Thomas (2008), discussed in the introduction, demonstrate that the southwest Kalahari dunes were experiencing episodic construction of their crests throughout the Holocene. While this does not rule out any role for dune erosion, it does imply that this sort of post-emplacement modification was probably limited, and it 
seems more likely that the southwest Kalahari dunes were originally emplaced with different morphometric relationships to the Namib simple linear dunes.

\section{Conclusion}

This study has characterised the relationships between dune height, spacing and equivalent sand thickness of the fixed linear dunes of the southwest Kalahari. These relationships are compared to a similar analysis of the active simple linear dunes of the nearby Namib sand sea. Significant morphometric differences between the two sand seas are identified. Specifically, the dunes of the southwest Kalahari do not show the expected positive relationship between dune height and spacing, such as that found in the simple linear dunes of the Namib sand sea. Furthermore, lower values of EST are predicted for a given mean dune height in the southwest Kalahari compared to the simple linear dunes of the Namib sand sea. Mapping of these morphometric data show distinct patterns of height, spacing and EST in the southwest Kalahari dunefield. The dunes are taller and more closely spaced towards the southeast of the dunefield and the equivalent sand thickness is greater here.

Two possible interpretations for the morphometric differences between the simple linear dunes of the southwest Kalahari and the Namib sand sea are either that the southwest Kalahari dunes were formed under different conditions of wind regime and sediment supply, resulting in the observed different morphometric relationships, or that the southwest Kalahari dunes may have originally displayed similar relationships to those of the Namib sand sea, but subsequent environmental changes have modified these relationships. Detailed OSL dating of the southwest Kalahari dunes indicates that the crests have experienced episodic periods of accumulation during the Holocene, suggesting that post-emplacement erosion of the dunes is likely to have been limited, but further research is required to evaluate these two possibilities. Specifically, further morphometric studies of other fixed sand seas and dunefields are required, to determine if the patterns observed in the southwest Kalahari are representative of fixed dune systems elsewhere.

\section{Acknowledgements}

The authors would like to thank Matt Baddock and Ben Livingstone for field assistance, and the land owners within the study area for permission to access the dunes on their land for the field survey. Lisa Moran was employed on a Reading University Undergraduate Research Opportunities Programme (UROP) grant to the lead author.

\section{References:}

Ash, J. E. and Wasson, R. J. 1983. Vegetation and sand mobility in the Australian desert dunefield. Zeitschrit für Geomorphologie, 45, 1-25.

Baddock, M.C., Livingstone, I. and Wiggs, G.F.S. 2007. The geomorphological significance of airflow patterns in transverse dune interdunes. Geomorphology, 87, 322-336.

Besler H. 1980. Die Dünen-Namib: Entstehung und Dynamik eines Ergs. Stuttgarter Geographische Studien, 96.

Blumberg, D.G. 2006. Analysis of large Aeolian (wind blown) bedforms using the Shuttle Radar Topography Mission (SRTM) digital elevation data. Remote Sensing of Environment, 100, 179-189. 
Breed, C.S. and Grow, T. 1979. Morphology and distribution of dunes in sand seas observed by remote sensing. In A Study of Global Sand Seas, McKee, E.D. (Ed.) USGS Professional Paper 1052, 253-403.

Bubenzer, O. and Bolten, A. 2008. The use of new elevation data (SRTM/ ASTER) for the detection and morphometric quantification of Pleistocene megadunes (draa) in the eastern Sahara and the southern Namib. Geomorphology, 102, 221-231.

Bullard, J. E. 1994. The analysis of the morphological variation of linear sand dunes and their relationship with environmental parameters in the southwestern Kalahari, Unpublished PhD thesis, University of Sheffield.

Bullard, J.E. and Nash, D.J. 1998. Linear dune pattern variability in the vicinity of dry valleys in the southwest Kalahari. Geomorphology, 23, 35-54.

Bullard, J.E., Thomas, D.S.G., Livingstone, I. and Wiggs, G.F.S. 1995. Analysis of linear sand dune morphological variability, southwestern Kalahari dunefield. Geomorphology 11: 189-203.

Bullard, J.E., Thomas, D.S.G., Livingstone, I. and Wiggs, G.F.S. 1997. Dunefield activity and interactions with climate variability in the southwest Kalahari desert. Earth Surface Processes and Landforms, 22, 165-174.

Bullard, J.E., White, K. and Livingstone, I. 2011. Morphometric analysis of aeolian bedforms in the Namib Sand Sea using ASTER data. Earth Surface Processes and Landforms, 36, 1534-1549. DOI: 10.1002/esp.2189

Bullard, J.E., Wiggs, G.F.S. and Nash, D.J. 2000. Experimental study of wind directional variability in the vicinity of a model valley. Geomorphology, 35, 127-143.

Eriksson, P.G., Nixon, N., Snyman, C.P. and Bothma, J. du P. 1989. Ellipsoidal parabolic dune patches in the southern Kalahari Desert. Journal of Arid Environments, 16, 111-124.

Fitzsimmons, K.E. 2007. Morphological variability in the linear dunefields of the Strzelecki and Tirari deserts, Australia. Geomorphology, 91, 146-160.

Frank, A. and Kocurek, G. 1996. Toward a model for airflow on the lee side of aeolian dunes. Sedimentology, 43, 451-458.

Goudie, A.S. 2002. Great Warm Deserts of the World. Oxford: Oxford University Press, 444pp.

Grove, A.T. 1969. Landforms and climatic change in the Kalahari and Ngamiland. Geographical Journal, 135, 191-212.

Hugenholtz, C.H. and Barchyn, T.E. 2010. Spatial analysis of sand dunes with a new global topographic dataset: new approaches and opportunities. Earth Surface Processes and Landforms, 35, 986-992.

Hugenholtz, C.H., Levin, N., Barchyn, T.E. and Baddock, M.C. 2012. Remote sensing and spatial analysis of aeolian sand dunes: a review and outlook. Earth Science Reviews, 111, 319-334. 
Kiss, T., Sipos, G. and Kovácsm F. 2009. Human impact on fixed sand dunes revealed by morphometric analysis. Earth Surface Processes and Landforms, 34, 700-711.

Kocurek, G., Townsley, M., Yeh, E., Havholm, K. and Sweet, M.L. 1992. Dune and dunefield development on Padre Island, Texas, with implications for interdune deposition and water-tablecontrolled accumulation. Journal of Sedimentary Petrology, 62, 622-635.

Lancaster, N. 1987. Formation and reactivation of dunes in the southwestern Kalahari: palaeoclimatic implications. Palaeoecology of Africa, 18, 103-110.

Lancaster, N. 1988a. Development of linear dunes in the southwest Kalahari, southern Africa. Journal of Arid Environments, 14, 233-244.

Lancaster, N. 1988b. Controls of eolian dune size and spacing. Geology, 16, 972-975.

Lancaster, N. 1989. Late Quaternary paleoenvironments in the southwestern Kalahari.

Palaeogeography, Palaeoclimatology, Palaeoecology, 70, 367-376.

Lancaster, N. 1995. Geomorphology of Desert Dunes. Routledge: London.

Lancaster, N. 2009. Dune morphology and dynamics. In Geomorphology of Desert Environments, $2^{\text {nd }}$ ed., Parsons A.J. and Abrahams A.D. (eds). Springer, 557-596.

Livingstone, I. 2013. Aeolian geomorphology of the Namib Sand Sea. Journal of Arid Environments, 93, 30-39.

Livingstone, I., Bristow, C., Bryant, R.G., Bullard, J.E., White, K. and Wiggs, G.F.S. 2010. The Namib Sand Sea digital database of aeolian dunes and key forcing variables. Aeolian Research, 2, 93-104.

Mabbutt, J.A. and Wooding, R.A., 1983. Analysis of longitudinal dune patterns in the northwestern Simpson Desert, central Australia. Zeitschrift für Geomorphologie N. F. Supplementband, 45, 51-69.

Mainguet, M. and Chemin, M-C. 1983. Sand seas of the Sahara and Sahel: an explanation of their thickness and sand dune type by the sand budget principle. In Eolian Sediments and Processes, Brookfield M.E. and Ahlbrandt, T.S. (eds). Elsevier: Amsterdam, 353-364.

McKee, E.D. (Ed.) 1979. A Study of Global Sand Seas. USGS Professional Paper 1052, 1-19.

Miller, R. McG. 2014. Evidence for the evolution of the Kalahari dunes from the Auob River, southeastern Namibia. Transactions of the Royal Society of South Africa, 69, 195-204, DOI:10.1080/0035919X.2014.955555

Muhs, D.R. and Holliday, V.T. 1995. Evidence of active dune sand on the Great Plains in the $19^{\text {th }}$ Century from accounts of early explorers. Quaternary Research, 43, 118-124.

Potts, L.V., Akyilmaz, O., Braun, A. and Shum, C.K. 2008. Multi-resolution dune morphology using Shuttle Radar Topography Mission (SRTM) and dune mobility from fuzzy interference systems using SRTM and altimetric data. International Journal of Remote Sensing, 29, 2879-2901. 
Rabus, B., Eineder, M., Roth, A. and Bamler, R. 2003. The Shuttle Radar Topography Mission, a new class of digital elevation models acquired by spaceborne radar. ISPRS Journal of Photogrammetry and Remote Sensing, 57, 241-262.

Slater, J.A. 2011. Global Assessment of the New ASTER Global Digital Elevation Model. Photogrammetric Engineering and Remote Sensing, 77, 335-349.

Stone, A.E.C. and Thomas, D.S.G. 2008. Linear dune accumulation chronologies from the southwest Kalahari, Namibia: challenges of reconstructing late Quaternary palaeoenvironments from aeolian landforms. Quaternary Science Reviews, 27, 1667-1681

Sweeney, M.R. and Loope, D.B. 2001. Holocene dune-sourced alluvial fans in the Nebraska Sand Hills. Geomorphology, 38, 31-46.

Talbot, M.R. and Williams, M.A.J. 1978. Erosion of fixed dunes in the Sahel, Central Niger. Earth Surface Processes, 3, 107-113.

Telfer, M.W., Fyfe, R.M. and Lewin, S. Automated mapping of linear dunefield morphometric parameters from remotely-sensed data. Aeolian Research (2015).

http://dx.doi.org/10.1016/j.aeolia.2015.03.001

Telfer, M.W. and Thomas, D.S.G. 2007. Late Quaternary linear dune accumulation and chronostratigraphy of the southwestern Kalahari: implications for aeolian palaeoclimatic reconstructions and predictions of future dynamics. Quaternary Science Reviews, 26, 2617-2630.

Thomas, D.S.G. 1988. Analysis of linear dune-sediment-form relationships in the Kalahari dune desert. Earth Surface Processes and Landforms, 13, 545-553.

Thomas, D.S.G. and Burrough, S.L., Luminescence-based dune chronologies in southern Africa: Analysis and interpretation of dune database records across the subcontinent, Quaternary International (2013), http://dx.doi.org/10.1016/j.quaint.2013.09.008

Thomas, D.S.G. and Leason, H.C. 2005. Dunefield activity response to climate variability in the SW Kalahari. Geomorphology, 64, 117-132.

Twidale, C.R. 1972. Evolution of sand dunes in the Simpson Desert, central Australia. Transactions of the Institute of British Geographers, 56, 77-110.

van Rooyena, N. and van Rooyena, M. W. 1998. Vegetation of the south-western arid Kalahari, an overview. Transactions of the Royal Society of South Africa, 53, 113-140.

Vance, R.E. and Wolfe, S.A. 1996. Geological indicators of water resources in semi-arid environments: southwestern interior of Canada. In Geoindicators, Berger, A.R. and lams, W. (Eds.). Balkema: Rotterdam, 251-263.

Wasson, R.J., Fitchett, K., Mackey, B. and Hyde, R. 1988. Large-scale patterns of dune type, spacing and orientation in the Australian continental dunefield. Australian Geographer, 19, 89-104.

Wasson, R. J. and Hyde, R. 1983a. Factors determining desert dune type. Nature, 304, 337-339. 
Wasson, R. J. and Hyde, R. 1983b. A test of granulometric control of desert dune geometry, Earth Surface Processes and Landforms, 8, 301-312

Wiggs, G.F.S., Bullard, J.E., Garvey, B. and Castro, I. 2002. Interactions between airflow and valley topography with implications for aeolian sediment transport. Physical Geography, 21, 366-380.

Wiggs, G. F. S., Livingstone, I., Thomas, D. S. G. and Bullard, J. E. 1996. Airflow and roughness characteristics over partially vegetated linear dunes in the southwest Kalahari Desert. Earth Surface Processes and Landforms, 21, 19-34.

Wiggs, G. F. S., Thomas, D. S. G., Livingstone, I. and Bullard, J. E. 1995. Dune mobility and vegetation cover in the southwest Kalahari Desert. Earth Surface Processes and Landforms, 20, 515-529.

Wilson, I.G. 1972. Aeolian bedforms - their development and origins. Sedimentology, 19, 173-210.

Wilson, I.G. 1973. Ergs. Sedimentary Geology, 10, 77-106. 